\title{
Transfersal Transformation: From Personal Analysis to Social Analysis According to Calvin and Ricoeur
}

\author{
John C. Simon \\ The Center for Religious and Philosophy Studies (CRPS) in Makassar, Indonesia \\ tajaksebakal@gmail.com
}

\begin{abstract}
:
Two figures who live in different ages, Calvin and Ricoeur, have built their thinking by way of an experience of repentance or self-renewal. This is the experience that is called as personal analysis. Calvin, with his experience of "sudden conversion (subita conversio)", was moved to undertake a better world transformation as the stage of God's glory. Ricoeur, with his concept of "self-consciousness", emancipated the open subject aimed at social emancipation. Their experiences are individual in character, but it isn't closed, conversely opened and forwarded out to others through relationships with others in the context of living together. Its goal is a social analysis through the transformation of a good and just life. The shifting process from personal analysis to social analysis, I call it as a transfersal transformation, namely, a change in the private realm that is forwarded to the public sphere with a call to live a good and fair life together. In Asia, the shift from personal analysis to social analysis (transfersal transformation) is important for Asian theology to be contextual and design a good and just society.
\end{abstract}

\section{Keywords:}

transfersal transformation, personal analysis, social analysis, Calvin and Ricoeur.

"I call 'piety' that reverence joined with love of God which the knowledge of his benefits induces"

(John Calvin $)^{1}$

"All reflection is mediated, there is no immediate self-consciousness"

(Paul Ricoeur) $)^{2}$

1 John Calvin, Institutes of the Christian Religion, ed. John T. McNeill, (Louisville, Kentucky: Westminster John Knox Press, 2006), I, 41.

2 Paul Ricoeur, Essays on Biblical Interpretation, ed. Lewis S. Mudge, (Philadelphia: Fortress Press, 


\section{INTRODUCTION}

Of course, it isn't of easy to construct the thoughts of these two figures, Jean Cauvin whom by English readers has been known as John Calvin and Jean Paul Gustave Ricoeur or commonly called Paul Ricoeur. First, these two figures clearly lived in different times. Cavin lived in the 16 th century, while Ricoeur in the 20 th century. Time span of 500 years between these two figures makes it difficult to explain the relationship between them. Second, the difference of generation and age certainly presents the different context challenges. In their respective days, Calvin and Ricoeur dealt with a typical context challenge. Another difficulty is, as far as I know, no one has done a serious study by delving into the relationship between Calvin and Ricoeur or their interrelated thoughts. So this work is obviously going to face its own difficulties. However, I am still optimistic that this effort is workable.

In my opinion, one of the connecting points that can bring these two figures together is what Kees Bertens has said about Ricoeur that "He is from a devout Protestant Christian family and is considered one of the foremost Protestant scholars in France". ${ }^{3}$ Bertens's note presents what, in the hermeneutic study, is understood as a symbol, viz., Christian Protestant and French. The symbol is noteworthy considering that Calvin and Ricoeur are both from France. Further, these two symbols are important for the imaginative interpretation aiming to reach a further understanding. Imagination is a dimension of the subject which answers text as a creator of "something". What is the "something"? The new possibilities for the "self-responsibility that is presented by text through imagination. ${ }^{4}$ Without an imagination there will never be an action.

As we know, Calvin is a church reformer from France and I assume that Ricoeur came from a family of Calvinist Protestants. Or, at least, as a Protestant, Ricoeur must have known Calvin, his thoughts, and the Huguenot sects, the French Protestants, inspired by Calvin' writings. In Wikipedia, there is little information that the Ricoeur family is a devout member of the Huguenot sect, the French Protestants who are minor compared to the majority Catholics.

1980), 68 .

3 K. Bertens, Sejarah Filsafat Kontemporer: Prancis, Jilid II, (Jakarta: Gramedia, 2014), 247.

4 Paul Ricoeur, From Text to Action: Essays in Hermeneutics, II, trans. Kathleen Blamey and John B. Thompson, (Evanston, Illinois: Northwestern University Press, 1991), 38. 
This paper attempts to explain the relationship between Calvin and Ricoeur, particularly the theme of self-consciousness and its relation to a transformative ethical call. In Asia, the power of transformative social analysis is supported by a critical and liberating personal analysis. Calvin's and Ricoeur's thinking are linked to a personal analysis as the initial step towards social analysis that is equally liberating. Hence, first, I will explain Calvin and his conversion experience. For Calvin, self-awareness is directly related to a spirituality generated by a sudden conversion experience (subita conversio). The conversion opens the door for real involvement in the problems of the world. Furthermore, I will explain Ricoeur with his self-consciousness project which is the main goal of his emancipatory hermeneutics. A self-emancipation that Ricoeur intends lead to a social emancipation. Finally, I will explain an idea that unites the two figures of the different age by means of the transfersal transformation of subjectivity and its embodiment in the contemporary tasks.

\section{Calvin and Subita Conversio}

When Lutheranism began to fade, John Calvin appeared and continued the reform. Like Luther, Calvin also hoped that the church renewal could take place peacefully. Calvin sought a renewal of the church and not a separation from the Roman Catholic Church. The separation is actually forced upon him under the threat of cursing and killing. Calvin recalled with sadness what his predecessor, Luther, had done and he himself now do,

"[...] Luther first acted with all his humility [...] he prefers the desire for improvement [...] When our party proposes a settlement by way of negotiations in a calm and friendly atmosphere, they are pursued with arrest instructions and murder, finally reaching this sad partying ". 5

In church history, John Calvin is 25 years younger than Martin Luther. ${ }^{6}$ Calvin began the church reform in France when there was an absolute monarchy. With her motto un roi, une loi, une foi, (one king - one law - one faith), France was left no room at all for the reform movement to flourish. ${ }^{7}$ The French Protestants or better known as the Huguenots

5 W.F. Dankbaar, Calvin:Jalan Hidup dan Karyanya, (Jakarta: BPK, 1967), 26-27.

6 Bernard Cottret, Calvin:A Biography, (T \& T Clark: Grand Rapids, Michigan, 1995), 39.

7 Cottret, Calvin: A Biography, 40-43. Christopher Elwood, Calvin for Armchair Theologians, (Louisville, London: Westminster John Knox Press, 2002), 13. Agustinus M.L. Batlajery, "Keesaan 
(Eidguenots, confederates) suffered great inhibitions, persecutions, and massacres for their choice to follow the ideals of the reformers including those of Calvin's.

What is the power behind Calvin? The great power that moved him to renew the church was an experience of conversion. Calvin's conversion experience can be depicted as what Bernard Lonergan calls "being in love". ${ }^{8}$ Being in God's love is radical because it is a total surrender. When a person falls in love he has an actual ability for self-transcendence. In Calvin's experience, the impetus to self-transcendence and authenticity was firmly based on an experience of God's love. Love gets people involved, toward a union, toward enlightenment, repentance. A true mystic always reads the scriptures and lives them. Likewise, Calvin was a man who familiar with Scripture that was read not with an intellectual intention but rather existential meditation. ${ }^{9}$ Through Scripture, he experienced what Scholastic theology calls visio beatifica (see God) through a process of "sudden conversion" (subita conversio) in response to God's love. ${ }^{10}$ Although it looks somewhat controversial, Bernard Cottret described Calvin's repentance thus, "His conversion undoubtedly occurred during the years 1532-33 [...] God chose Calvin, Calvin did not choose God: this is the very formula of an election. God mysteriously chooses certain beings. God chooses in the same way as he rejects, without reason, by the arbitrary action of his grace" ${ }^{11}$ And the experience of being loved by God and loves Him culminates in the birth of piety.

What is piety (pietas)? In the Institutes, Calvin explains it thus: "I call 'piety' that reverence comes with love of God which is the knowledge of his benefits induces." 12 This love of God is primordially pertinent with what Calvin said about "divine consciousness" (sensus divinitatis), ${ }^{13}$ viz.

Gereja Menurut Calvin dalam Institutio 1536”, Studia 11, Nr. 1, (Maret 2011$) 132$.

8 Bernard J.F. Lonergan wrote: "All love is self-surrender, but being in love with God is being in love without limits or qualifications or conditions or reservations”. See Bernard J.F. Lonergan, Method in Theology, (London: Darton, Longman \& Todd, 1975), 105-106.

9 Hugh Thomson Kerr, Jr., A Compendium of the Institutes of the Christian Religion by John Calvin, (Philadelphia: Presbyterian Board of Christian Education, 1939), 13-19. William Johnston, Mistik Kristiani: Sang Rusa Terluka, trans. A. Soenarja, (Yogyakarta: Kanisius, 1987), 17, 39.

10 Elwood, Calvin for Armchair Theologians, 10. Cottret, Calvin:A Biography, 68-69, 120.

11 Cottret, Calvin: A Biography, 66.

12 Calvin, Institutes of the Christian Religion, I, 41.

13 Serena Jones, Calvin and the Rhetoric of Piety, (Louisville, Kentucky: Westminster John Knox 
a strong sense or awareness of the gracious presence of God in every human being. In Institutes, Calvin said:

"There is within the human mind, and indeed by natural instinct, an awareness of divinity. This we take to be beyond controversy. To prevent anyone from taking refuge in the pretense of ignorance, God himself has implanted in all men a certain understanding of his divine majesty. Ever renewing its memory, he repeatedly sheds fresh drops". ${ }^{14}$

The so-called sensus divinitatis, and another term, semen religionis (the seed of religion) are a strong awareness of God's presence or a religious feeling that inherent in men. It is this awareness or feeling guiding everyone to religious activities and ethical virtues as part of the "regeneration" (regeneratio). ${ }^{15}$ About this, Calvin said: "free will is not sufficient to enable man to do good works, unless he is helped by grace, indeed by special grace, which only the elect receive through regeneration”. ${ }^{16}$ Here the role of grace becomes important and decisive. Calvin's spirituality puts grace as the divine power that enables men to do good deeds. The God's grace is a special gift that enables everyone to be open and directed to the world and called to change the world. ${ }^{17}$ There is no opposition between God's grace and the call to struggle for justice. And God's grace gets its most radical form in a just action for others.

Talking about grace, it leads us to the typical terminology in Calvin's spirituality, viz. "unio cum Christo" (union with Christ). ${ }^{18}$ Calvin learned the idea of a mystical union (unio mystica), namely, relationship with Christ and fellow human beings (inseparable), from a theologian and mystic, Bernard of Clairvaux, who has deeply influenced him. ${ }^{19}$ This means that Calvin's longing for unity with the Divine, besides rooted in his painful experience due to the church splits at his time, also based on the work of Christ's mission uniting everyone in Him. And the unity with

Press, 1995), 161-162.

14 Calvin, Institutes of the Christian Religion, I, 43.

15 E.G. Singgih, Mengantisipasi Masa Depan: Berteologi dalam Konteks di Awal Milenium III, (Jakarta: BPK Gunung Mulia, 2005), 268.

16 Calvin, Institutes of the Christian Religion, II, 262.

17 Calvin, Institutes of the Christian Religion, II, 262.

18 Gijsbert van den Brink and Johan Smits, “The Reformed Stance: Distinctive Commitments and Concerns”, Journal of Reformed Theology, Nr. 9, (2015) 332, f.n. 23.

19 Van den Brink and Smits, “The Reformed Stance”, 332, f.n. 23. 
Christ gets its most radical manifestation in a reciprocal relationship and living a fair common life with others. Here, Agustinus Batlajery's explanation relieved us from the dark pages of the Reformation history that Calvin described it as not directly involved in the execution Michael Servetus at the stake. ${ }^{20}$ Calvin's efforts to seek amnesty and save Servetus from the power of the Geneva council of churches shows that he was consistent with his pious and tolerant anthropological theology that doesn't want to repeat the mistakes of history through divisions and even bloodshed.

In addition to Bernard of Clairvaux, Calvin was deeply inspired by other church Fathers who taught about the most important thing in Christianity, that is, humility. Of Chrysostomus, Calvin says, "A saying of Chrysostom's has always pleased me so much, that the foundation of our philosophy is humility". ${ }^{21}$ Calvin also greatly idolized Augustine in regard to his doctrine of humility. Calvin recalled what Augustine once said, "so, if you ask me concerning the precepts of the Christian Religion, first, second, and third, and always I would answer, 'Humility". ${ }^{22}$ Through humility, living with others becomes a celebration of various charisms. In pertinent with Calvin's idea of the church's new life, humility creates a place for learners to absorb wisdom from anywhere. Humility is a part of "regeneration," a process of catching God's mystery presenting through other mediations. In a "rebirth" there is no dichotomy between faith and deed. The "rebirth" is manifested in social, economic and political responsibility.

The Institutes begin with the description of how a man can know God (knowledge of God). ${ }^{23}$ The term "knowledge" that Calvin translated as "to know", actually is not in a purely rational and abstract scientific sense and achieved thorough a rigid and rigorous processes, but in an intuitive sense which is gained through experience. The Institutes even clearly states that the experience is contemplative about God. ${ }^{24}$ Calvin apparently was influenced by early theologians especially Augustine who did not distinguish between spirituality or mystical theology and

20 Agustinus M.L. Batlajery, “Calvin and Servetus: A Case of Violence and Calvin's Involvement”, Sola Experientia 2, Nr. 1, (April 2014) 17-27 (26).

21 Calvin, Institutes of the Christian Religion, II, 268.

22 Calvin, Institutes of the Christian Religion, II, 268-269.

23 Calvin, Institutes of the Christian Religion, I, 35.

${ }^{24}$ Calvin, Institutes of the Christian Religion, I, 35. 
knowledge. "For Augustine, God is known not by scientia but by sapientia - that is to say, not by objectification and analysis but a contemplative knowledge of love and desire." 25 In an effort to understand Calvin's experience of conversion, and his Institutes, in which the key term in mystical theology, that is, "piety" clearly mentioned, and its ecumenical form as the unity of the church, Phillip Sheldrake did not hesitate to say that the Institutes of the Christian Religion is a work of spiritual theology. ${ }^{26}$

Knowing God (knowledge), for Calvin, means knowing oneself including knowing through God's representative mediation encountered in suffering fellows. In general, the whole world is a mediation to know God. Of this, John H. Leith said that "Calvin's conviction that we know God with the same immediacy as we know the reality of the world or ourselves is rooted in this engagement with the reality that impinges upon us on the boundary of life". ${ }^{27}$ Therefore, knowing God is inseparable from the call for piety. Piety itself is closely related to the anthropological meaning that its embodiment not only in diligence of worship and pray but chiefly in the activity of doing goods for the sanctification of life in this world. ${ }^{28}$ Realization of piety is not just an anthropological, but also a cosmological, that is, covers the whole world. The world becomes a vast area for various activities of doing goods. This is what so-called in Mattew Fox's term as the self-consciousness achieved by getting out of the self, emptying the self and not attached to (letting go) anything that can divert our view from loving God. ${ }^{29}$ To love God means to love all of God's creation.

The question of kindness, compassion, and care, it is a matter of treating this world as the theatrum gloriae Dei, ${ }^{30}$ namely, makes the world as a stage of God's glory. As a stage, this world is a place where God's love is met with, or forwarded in love to, others and other creatures. Calvin's

25 Calvin, Institutes of the Christian Religion, I, 35.

26 Philip Sheldrake, Spirituality and Theology: Christian Living and the Doctrine of God, (Maryknoll, New York: Orbis Books, 1998), 46.

27 John H. Leith, The Reformed Imperative:What the Church Has to Say That No One Else Can Say, (Philadelphia: The Westminster Press, 1988), 45.

28 Jones, Calvin and the Rhetoric of Piety, 150, 161. Lucien Joseph Richard, The Spirituality of John Calvin, (Atlanta, Georgia: John Knox Press, 1974), 90, 178-180.

29 Matthew Fox, Breakthrough: Meister Eckhart's Creation Spirituality in New Translation, (New York: Image Books, 1980), 210.

30 Christiaan de Jonge, Apa itu Calvinisme?, (Jakarta: BPK Gunung Mulia, 2011), 386. 
ideal of life is for the greater glory of God, Ad Maiorem Dei Gloriam. The ideal close to what is also shared by the founder of the Society of Jesus (Jesuit), Ignatius of Loyola, who was Calvin's contemporaries, and even his fellow student in Montaigu under the guidance of John Mair. ${ }^{31}$ The Jesuits' and Calvin's motto is the same, i.e. Ad Maiorem Dei Gloriam. Calvin also describes the ideal of the believer as the contemptus mundi ${ }^{32}$ or also called cotemplativus in actione, i.e. one who does not run away or attaches himself to the world, but to God alone, and lives the contemplative life in daily action, seeks and finds God in daily experiences.

Calvin's spirituality, which inseparable from solidarity and social involvement, is not based on the doctrine of human depravity that is often ascribed to him. The doctrine of total human depravity, in fact, stemmed from the Dutch Creed, influenced by the extremely rigid theology of Calvinist Orthodoxy with its political interests. ${ }^{33}$ He himself still appreciated the "reason" as a God-given man's natural constituent that doesn't suffer total damage when the first men had fallen into sin. With the reason, men can still distinguish the good and the bad, and have the desire to seek the truth. Calvin said it at length:

"Since reason, therefore, by which man distinguishes between good and evil, and by which he understands and judges, is a natural gift, it could not be completely wiped out; but it was partly weakened and partly corrupted, so that its misshapen ruins appear [...] in man's perverted and degenerated nature some sparks still gleam. These show him to be a rational being [...] When we so condemn human understanding for its perpetual blindness as to leave it no perception of any object whatever, we not only go against God's Word, but also for the experience of common sense. For we see implanted in human nature some sort of desire to search out the truth $[\ldots] "{ }^{34}$

According to Calvin, reason does not go damaged, because it is a part of God's gift. What Calvin says precisely similar to what Lonergen meant by reason as the driving force toward transcendence and self-authen-

31 Dankbaar, Calvin, 12. Cottret, Calvin: A Biography, 20.

32 H.W.B. Sumakul, Panggilan Iman dalam Teologi Luther dan Calvin: Suatu Kajian Etika Sosial Politik dalam Gereja Reformasi, (Jakarta: BPK Gunung Mulia, 2016), 132.

33 Th. van den End, Enam Belas Dokumen Dasar Calvinisme, (Jakarta: BPK Gunung Mulia, 2011), 30. See also Van den Brink dan Smits, "The Reformed Stance “, 332.

34 Calvin, Institutes of the Christian Religion, II, 270-271. 
ticity. ${ }^{35}$ Since the reason is a grace, it is also the instrument of divine love living in all men and provides the impetus to unite with the divine including in real actions. The reason is conferred and become a means of the divine love in real actions in this world.

\section{Ricoeur and the Self Awareness Project}

Ricoeur's hermeneutic is, in fact, a critique of classical hermeneutics centering on a closed rational subject and intends to be the center of everything. For Ricoeur, the imprisoned and closed subject, that immune to any relationship, hinders the birth of the individual and social emancipation. About this he says: "Every hermeneutics is thus, explicitly or implicitly, self-understanding by means of understanding others". ${ }^{36}$ Hence, Ricoeur's emancipatory hermeneutic is, primarily, an emancipation of the subject, ${ }^{37}$ to free itself from the egoistic nature and be open to the social emancipation in fair common life institutions. Ricoeur describes this social emancipation as "'ethical intention' aiming at the 'good life' with and for others, in just institution". ${ }^{38}$

From a historical perspective, the emancipation hermeneutic of self-consciousness is inseparable from the various "symptom" that has been emerged in the search history of the "ultimate principle" (Being), that which, in Western philosophy, becomes a universal principle and has been used to explain everything. Western philosophy is a way of thinking begins with the ego and returns to it. This is a thought construction that is based on a rational ego (subject) and centering to it, what the so-called ontology. ${ }^{39}$ It was illustrated in Ricoeur's critical dialogue with

35 Lonergan, Method in Theology, 111. William Johnston, Teologi Mistik: Ilmu Cinta, (Yogyakarta: Kanisius, 2001), 254.

36 Paul Ricoeur, The Conflict of Interpretations: Essays in Hermeneutics, ed. Don Ihde, (Evanston: Northwestern University Press, 1974), 17.

37 Ricoeur wrote: "that the interpretation of a text culminates in the self-interpretation of a subject who thenceforth understands himself better, understands himself differently, or simply begins to understand himself". See Paul Ricoeur, Hermeneutics and the Human Sciences: Essays on Language, Action and Interpretation, ed. John B. Thompson, (Cambridge: Cambridge University Press, 1982), 158. Ricoeur wrote: "I understand myself only by means of the signs that I give of my own life and that are returned to me via others. All self-knowledge is mediated through signs and works". See Ricoeur, From Text to Action, II, 61-62.

38 Paul Ricoeur, Oneself as Another, trans. Kathleen Blamey, (Chicago and London: The University of Chicago Press, 1992), 172.

39 About this ontology I based my opinion on Ricoeur's opinion: "The short route is the one taken 
some great thoughts are called school of Descartes, ${ }^{40}$ i.e. Cartesianism (Descartes), Positivism (A. Comte), Phenomenology (E. Husserl), Romanticism (F. Schleiermacher and W. Dilthey) and Structuralism (F. de Saussure).

Ricoeur characterizes the entire thought frameworks i.e. positivism, phenomenology, romanticism and structuralism as traceable to the effect of the anti-emancipation Cartesian cogito. All thoughts that Ricoeur called as the school of Descartes, ${ }^{41}$ traceable to the Cartesian paradigm, i.e. the thought starting since Rene Descartes echoed sum cogitos, ergo sum cogitans (I think, therefore I am a thinking thing), that has framed a closed way of thinking, interest-free and was devoted to science without ethical touch. ${ }^{42}$ This Cartesian paradigm has spawned a hermeneutics called as the cogito hermeneutics, i.e. a closed and value-free reason. ${ }^{43}$ In addition, the positivist paradigm also contributes to widening the gap between the study of text and concern of the context. ${ }^{44}$ Interpreting the text becomes an activity devoid of a calling to bring it into concrete life. This paradigm has given birth a positivistic hermeneutics that indifferent to social engagement. Phenomenology also has a contribution to the model of closed knowledge in its claims of the existence of immediate recognition toward "something" without the need for mediation. As a result, social relationships minus from concerns toward the life condition of the "others". So it is with romanticism (romantic hermeneutics) obsessed with the restoration of the past by way of reproduction efforts which leads it away from criticism of understanding. ${ }^{45}$ Their famous jargon is "the ultimate aim of hermeneutics is to understand the author

by an ontology understanding, after the manner of Heidegger. I call such an ontology of understanding the "short route"”. See Ricoeur, The Conflict of Interpretations, 6.

40 Ricoeur, The Conflict of Interpretations, 148-149.

${ }^{41}$ Ricoeur, The Conflict of Interpretations, 148-149. David M. Kaplan, Ricoeur's Critical Theory, (New York: State University of New York Press, 2003), 23.

42 Ricoeur, Hermeneutics and the Human Sciences, 76, 89, 191.

43 Ricoeur wrote: "Cogito for my understanding, it has certainty only within it, that is, for my self enclosed within itself”. See Ricoeur, Oneself as Another, 8.

44 Paul Ricoeur, Interpretation Theory: Discourse and The Surplus of Meaning, (Texas: The Texas Christian University Press, 1976), 71-88. John B. Thompson, Critical Hermeneutics: A Study in the thought of Paul Ricoeur and Jürgen Habermas, (Cambridge: Cambridge University Press, 1981), 36. F. Budi Hardiman, Kritik Ideologi: Menyingkap Pertautan Pengetahuan dan Kepentingan Bersama Jürgen Habermas, (Yogyakarta: Kanisius, 2010), 26.

45 Ricoeur, Hermeneutics and the Human Sciences, 67. 
better than he understands himself". ${ }^{46}$ Obsession with the past, viz. the author's lifetime, hinder the emergence of criticism of the supposedly okay past. An exaggerated appreciation of the past (including the author), unwittingly raises the concept of ideology allegedly neutral knowledge while hiding interests. The romanticism of the past is an ideology that is often perpetuated to defend domination. And finally, in dealing with the structuralism philosophy, ${ }^{47}$ hermeneutics loses its historical aspect. ${ }^{48}$ Whereas, historical consciousness is the aspect of time and place (read: the context) in which human problems such as pluralism, poverty, suffering, injustice, and ecological damage occurs. As a result, the hermeneutics is away from concerns over the context. The task of Ricoeurs' emancipation hermeneutics is consciously tethered to historical consciousness or to historical experience so that all the intentions of the liberation effort are really rooted in the history of concern. This is the meaning behind Ricoeur's statement that "hermeneutics without a project of liberation is blind, but a project of emancipation without historical experience is empty". ${ }^{49}$

In the context as above, Ricoeur needs a hermeneutic that is tethered to the historical experience and aimed at new self-understanding, while at the same time understanding the world and others. This is a reflective philosophy of the subjectivity renewal, which in Ricoeur own words, aiming at: "to achieve self understanding while at the same time understanding the world and other people". ${ }^{50}$ It is also referred to as "transformative hermeneutic" 51 that responsive to the challenges being faced today's by religious communities by way of interpreting themselves and the context through a new eyeglasses.

Ricoeur's dialogue partners for the subjectivity transformation project can be grouped into three parts. First, Ricoeur received input from

46 Ricoeur, Hermeneutics and the Human Sciences, 151.

47 Paul Ricoeur, The Rule of Metaphor, trans. Robert Czerny, Kathleen McLaughlin and John Costello, (London and New York: Routledge Classics, 2003), 85. Zainal Abidin, Filsafat Manusia: Memahami Manusia Melalui Filsafat, (Bandung: Remaja Rosdakarya, 2006), 215-234.

48 Thompson, Critical Hermeneutics, 41-42. S.H. Clark, Paul Ricoeur, (London dan New York: Routledge, 1990), 92-93.

49 Paul Ricoeur, Lectures on Ideology and Utopia, ed. George H. Taylor, (New York: Columbia University Press, 1986), 237.

50 Ricoeur, From Text to Action, II, 132. Kaplan, Ricoeur's Critical Theory, 9.

51 Ricoeur, The Conflict of Interpretations, 266, 452. James P. Martin, “Toward a Post-Critical Paradigm”, New Testament Studies 33 (Cambridge: Cambridge University Press, 1987) 370-385. 
the figures of the school of suspicion i.e. Marx, Nietzsche and Freud, to step towards "transformation of subjectivity". The purpose of that transformation is to undermine the illusion of an absolute, exploitative and dominative subject. Secondly, Ricoeur also partnered with Habermas and Gadamer to bring together two hermeneutics gestures. The former is critical of the tradition of Enlightenment, while the latter is affirmative of the tradition of romanticism. In order to shape his hermeneutics thought, Ricoeur used these two hermeneutics gestures to assert the Bible's language on liberation, exodus and resurrection. According to Ricoeur, the interests of emancipation are no longer attractive, nor has any hope of liberty, if the tradition of the former exodus and resurrection were removed from the memory of mankind. Thirdly, Ricoeur had a dialogue with Levinas. He approved Levinas's criticisms against the extremely-closed and egological classical ontology in the history of Western philosophy. Even though Ricoeur critical is against Levinas's asymmetrical ethics, he used Levinas's thought as an entrance to the idea of transformation toward self-emancipation within the fair public institutions. Based on his proposal for a symmetrical ethics that requires mutual respect for each other equally, Ricoeur considered the importance of public institutions in the form of a democratic system as a public consensus in order to maintain a fairly living together.

The hermeneutics process, in Ricoeur' hands, becomes meditative that begins from the self (ego) and returns through the other. This is Ricoeur's attempt to transcend Western philosophical thinking that always starts with, and returns to, the self (ego). Ricoeur's hermeneutics process is not a short (short route), but deliberately take a long route (detour). Self-understanding is never immediately, but indirectly through a long process revolving through signs, symbols, texts, including through the presence of others. Others become the means of contemplation to find a new and different image of the self. Therefore, my response to others must be appreciative, for they become ethical events for the calling to an ethical responsibility. Why? Because the others are not found outside but within one's own self. This is a hermeneutic of the self. ${ }^{52}$ Inside me there are others (oneself as another). Moreover, as the ethical events, other positions become so divine, that seen as forms of God's own

52 Ricoeur, Oneself as Another, 297. Ricoeur, The Conflict of Interpretations, 266. 
presence that transforms the illusory subject who often appear arrogant and domineering. The other is a mystery that always evoke both questions and wonder in encountering with the Divine, because the other is a repentance vehicle for the new, just and better of self.

The new self, who has undergone a transformation, Ricoeur called it second naivete, viz. the new, the fair, and the open self in his relationship to the other. The self identity is formed through and by the existence of others. Ricoeur admitted that he got inspired of this second naivete concept in his dialogue with the theologian Karl Barth. According to Ricoeur, Barth meant the concept to explain the subject not as a central figure, instead of being a disciple of the language used in dialogue with others. Ricoeur said, "It was in fact Karl Barth who first taught me that the subject is not a centralizing master but rather a disciple or auditor of a language larger than itself". ${ }^{53}$ The subject is a disciple who is in a continuous learning position in his attempt to undermine the subject's illusion and become a new self.

Have a position as the continuous learning student is very important to a subject when he deals with the context and history of his concerns. Here there is a close connection between narrativity and historicity. Since history can not be reduced, a meaning is no longer dependent on the author's intent, but on the narration by new readers. ${ }^{54}$ Through an interpretation method which doesn't satisfied with the search of a meaning behind the text, but looking for it in front of the text, there is an opportunity for a new interpretation according to the reader's response. ${ }^{55}$ There is also an imaginative method of interpretation in which the interpretive process begins precisely with the context first then moves toward the text, and come back dialogically to the context. Imagination is the dimension of the subject that answers the text as the creator of "something". What "something"? It means that through the imagination a text presents new possibilities for "self-responsibility" ${ }^{56}$ The goal is that we do not just become the disciples of the text, but become disciples of action through responsible lives. The serious implications of the above

53 Paul Ricoeur, A Ricoeur Reader: Reflection and Imagination, ed. Mario J. Valdes, (Toronto dan Buffalo: University of Toronto Press, 1991), 473.

54 Ricoeur, Hermeneutics and the Human Sciences, 275.

55 Paul Ricoeur, Time and Narrative, Vol. 3, trans. Kathleen Blamey and David Pellauer, (Chicago dan London: The University of Chicago Press, 1988), 157-179 (166-167).

56 Ricoeur, From Text to Action, II, 38. 
methods are the retelling and reinterpretation of history that is often dominated by stories of kings and powerful people. A story has never been written from the perspective of those who are powerless, the poor, oppressed who die for calling for justice. Ricoeur says: "For history is not only the story (histoire) of triumphant kings and heroes, of the powerful; it is also the story of the powerless and dispossessed. The history of the vanquished dead crying out for justice demands to be told". ${ }^{57}$ The narrative of self clearly contains political implications for something that is transformative, for a critical interpretation of history can provide the alternative historical explanations for various events which will be interpreted in a new way.

\section{Towards a Transfersal Transformation Task}

The knowledge of the self is a problem of mediated interpretation (hermeneutics). There is no self-consciousness attainment in direct way, or without mediation. It is this consciousness that consisted in the experience of self-transformation, both in Calvin's conversion experience and Ricoeur's hermeneutic project, and also becomes a theme uniting the two figures of the different times. This transformation of subjectivity is only made possible by the "linguistic turn" 58 which constructs human existence through semantic mediation, viz. by interpreting the meaning of the language in a dialogical or interlocutory way. According to Ricoeur, "the language is the medium through which we understand ourselves". ${ }^{59}$ Ricoeur, in fact, wants to put emphasis on what he calls an interlocutory act or an allocutionary act. ${ }^{60}$ One important aspect of a discourse is to have a stating subject and it is addressed or directed to another subject. This is the idea referred to as the transfersal transformation, in which a discourse actor expresses himself in front of another subject. It has been formed a famous definition of discourse with " $4 \mathrm{~S}$ ": "someone says something to someone about something". ${ }^{61}$ This definition forms the

57 Kaplan, Ricoeur's Critical Theory, 60.

58 Paul Ricoeur, “Approaching the Human Person”, Ethical Perspectives 6, Nr. 1, (April 1999) 45.

59 Ricoeur, Hermeneutics and the Human Sciences, 142.

60 Ricoeur, From Text to Action, II, 14-19, 79.

${ }^{61}$ Ricoeur wrote: "Discourse consists of the fact that someone says something to someone abouth something”. See Paul Ricoeur, Figuring the Sacred: Religion, Narrative and Imagination, trans. David Pellauer, (Minneapolis: Fortress Press, 1995), 220. See also Ricoeur, The Conflict of Interpretations, 86-88 (88). Ricoeur, Time and Narrative, Vol. 1, 78. 
language as a communication, where dialogue is the essence structure of the discourse. For Ricoeur, any discourse is always an interlocutory act, which is relational, communicative, dialogical and never singularly independent. A discourse is an emancipatory act of the subject opening an intersubjective relationship. A person transfers himself to another, and vice versa. This interlocutionary action further confirms that the meaning can be communicated so the mutual process of self-renewal happens.

The purpose of meaning communication is to attain a self-understanding. ${ }^{62}$ Communication of meaning is one of the typical tasks of hermeneutics through mediation of signs, symbols, and texts including the presence of another different subject. An understanding is nothing but understanding yourself better by taking a "long detour" through symbols, metaphors, texts, and other humane behaviors found everywhere including from other cultures and religions. ${ }^{63}$ Here it is impossible for total mediation via intuition as if there is a direct transparency in the subject without requiring mediation, but rather through long-term mediation (long route), that is, understanding the other to arrive at the self-understanding. This is a hermeneutics effort to find others in oneself and own self in others. I call this process a transfersal transformation, the transformation that transcends oneself toward other's self so it is formed a new self, that different in its existence and action.

The process of doing theology in Asia requires the praxis of transfersal transformation. A transfersal transformation is required, among others, for religions in the process of theologizing. Religious maturity is determined by self-understanding. The pursuit of transparency in the public sphere of religions requires self-understanding (appropriation) that which is obtained by taking distance. One of such models is the ideological criticism, which is a means of self-purification (self-transparency). Dismantling the illusion of an ideological subject, in the form of personal or group interest, as well as conscious and unconscious motives, would be useful in avoiding the misuse of religion as a frightening and deadly monster. The transfersal transformation gives birth to a new

62 Ricoeur, Essays on Biblical Interpretation, 68. Ricoeur, Hermeneutics and the Human Sciences, 158. Ricoeur, From Text to Action, II, 61-62, 118-119.

63 Randolf C. Flores, "Wrestling with the Text Paul Ricoeur's Hermeneutics and the Historical-Critical Method in Biblical Exegesis”, Diwa XXVII, Nr. 2, (November 2002) 136. 
self (second naïvete), ${ }^{64}$ namely, the self in a mutual moral responsibility with others in a just institution, and in relation to religions, it means an open self in the inter-faith and cross-cultural cooperation.

In the cross-faith and cross-cultural cooperation, a community has a "vested interest" in the process of interpretation of experience according to their needs. The experience is meaningful because it is reinterpreted by and within the community. ${ }^{65}$ Interpretive community is crucial in interpreting a historical experience. The collective experience of this community or group can have a meaning that goes beyond their own faith and culture. In the context of religious conflicts experiences in Indonesia, for example, the interfaith and cross-cultural communities have interests to interpret the conflict historical experience for the purpose of the emancipation of common life. At the same time, the community keeps the distance so that the wound history of the conflict never exploited by anyone to destroy the common life.

Therefore, Ricoeur asserted that hermeneutics is not just a method or a way to gain understanding, but a paradigm or value system of the interpreter or interpretive community in understanding reality. ${ }^{66}$ This realization refers to the fact that the "value-free" or neutral conditions in approaching social reality are almost impossible. Hermeneutics is a paradigm that also called methodology, namely a philosophical assumption framing knowledge with values and interests carried by a researcher or community in approaching reality. Contrary to the Descartes' school paradigm and its derivative thoughts, assuming ultimate responsibility solely to one own self, hermeneutics for the relation of religions takes the ultimate responsibility for others. ${ }^{67}$ Going beyond the "disciple of the text" who responsible only for himself, hermeneutics move into "disciple of the action" answerable for the lives of others. A self, who takes responsibility for others of different religions, is a new self that which is the main goal of the Ricoeur's hermeneutics project.

By affirming the ultimate responsibility for the life of others, Ricoeur initiated a social emancipation in the space of religions' relationships.

64 Paul Ricoeur, Freud and Philosophy: An Essay on Interpretation, trans. Denis Savage, (New Haven: Yale University Press, 1970), 496.

65 Paul Ricoeur dan Andre LaCocque, Thinking Biblically, (Chicago and London: University of Chicago, 1998), ix-xiii.

${ }^{66}$ Ricoeur, Oneself as Another, 306.

67 Ricoeur, From Text to Action, II, 37-38. 
This is a paradigm which he calls a concrete hermeneutics paradigm. He called it concrete because the consciousness is directed to, and opened to, the interfaith life with all his context of life. Taking responsibility for the lives of others put the ethics as the basis of philosophy, as Ricoeur said, "philosophy is ethics", meant to attain liberation. In Ricoeur's own words, "philosophy is ethics, to the extent that it leads from alienation to freedom and beatitude". ${ }^{68}$ As a framework, Ricoeur's ethics of liberation consists of three components: (1) living a good life, (2) concern for the lives of others, and (3) mediated by just institutions. Hermeneutics is the task of interpreting texts and contexts to arrive at an ethical call as an transfersal transformation that steps outside and opened to a social transformation within the just institutions, viz. the interfaith community.

Ricoeur's thoughts above, in my opinion, deeply inspired by the ideas contained in Calvin's writings. Calvin, as a French Protestant (Huguenot), clearly understood that it was his conversion experience (that is, subita conversio) that moves him to pursue an ethical call for the world sanctification. There is no dichotomy between mystical experience and ethical calling here. The world as the stage of God's glory (theatrum gloriae Dei), becomes an open field to pursue the transformation works for justice and peace. In Calvin's conviction, God constitutes a political institution, just like any other social institution (marriage and employment in economics). Calvin's political theology is clearly described in the Institutio. According to Calvin, the task of a political institution is

"to cherish and protect the outward worship of God, to defend the doctrine of piety and the position of the church, to adjust our life to the society of men, to form our social behavior to civil righteousness, to reconcile us with one another, and to promote general peace and tranquility". ${ }^{69}$

For Calvin, civil government is responsible for the welfare and prosperity of general public. These Calvin' ideas, in contemporary context, are molded in Ricoeur's thought of a democratic state. Ricoeur explained democracy thus: "As for the definition of democracy in relation to power, I shall say that democracy is the form of government in which participation in the decision-making process is guaranteed for an ever increasing

68 Ricoeur, Freud and Philosophy, 45-46. Ricoeur, The Conflict of Interpretations, 329. The idea that philosophy is an ethics is Levinas' influence on Ricoeur's thought. See Ricoeur, Oneself as Another, $306,349$.

69 Calvin, Institutes of the Christian Religion, IV, 1487. 
number of citizens". ${ }^{70}$ In a democracy conflict is almost inevitable. Democracy is not a political regime without conflict. Conflict exists and can be negotiated by increasing the tension of widespread public participation in accordance with the rules of the game which is mutually agreed upon. Public participation, among others, has a form as the welfare and justice common life.

In the Asian context, Choan-Seng Song was known as an Asian theologian greatly-inspired by Calvin and his thoughts. He attributes the effort to glorify God with the sensitivity to human problems that are spilled over in Asia. Song wants to show his loyalty to Calvin's theology that God can not be learned apart from humans. God is found in relationships with humans, even more the weak and suffering. This is a Calvin's typical curvature of anthropological theology that Song reformulates to become a theo-anthropology. The point is, for Calvin, that knowing God (knowledge) is to know oneself, and it is attained, including, through the mediation of suffering fellows. This idea is highly contextual with the experience of Asians in knowing God, so the problematic humanity is the focus of theological problems. Song Says:

"God is not a theological problem. It is we human beings who are the problem for theology. Problematic humanity is the subject of theology. The business of theology is to see how God makes this problematic humanity less problematic. For this reason theo-logy must be anthropo-logy. The logos of theos is the logos of anthropos". ${ }^{71}$

It's clear, both for Calvin and Ricoeur, that what so-called as critical social analysis, critical political analysis, critical economic analysis and critical cultural analysis, shouldn't ignore the personal analysis as their basis, that which Calvin terms as "knowledge", in which there is no dichotomy between knowing God and knowing human being, and which Ricoeur calls "self-consciousness" or "self-understanding." The transfersal transformation is a personal analysis by which to observe how far a subject is really open and engaged in the life condition that he shared together with others. Openness means recognizing where is someone stands, what glasses he uses to look at, which values he holds and where he directs his concerns. A transfersal transformation is also an attempt to look for and to discover the will of God.

70 Ricoeur, From Text to Action, II, 335.

71 Choan-Seng Song, Tell Us Our Name: Story Theology From an Asian Perspective, (New York: Orbis Books, 1984), 37. 


\section{Closing Remarks}

A transfersal transformation contains not only self-renewal but also reality renewal. In this case, we are helped by Asian theologian Aloysius Pieris's conception that unseats the peak of the life of faith paradigm. While in the history of the Christian tradition we find a view that placed mystical contemplation as the peak, and then another view placed liturgy and sacrament. ${ }^{72}$ Pieris put forwarded an alternative paradigm: Love is Action. ${ }^{73}$ The real act of love is solidarity to the poor and the victims of exploitation. Pieris said: "Action is the expression of Love that sums up God's own inner Trinitarian life as well as God's liberating intervention in our personal and social history through God's partnership with the poor." The central place of God that changes one's life was also the faith instilling both Calvin and Ricoeur. Knowing God is inseparable from knowing others, especially those who are poor and suffering, as a mediation for a new conversion and self-understanding.

In Asia, a transfersal transformation is a worthwhile attempt for new relationships that transcend a closed self into an open self that comes out to others. Absolute and arrogant subjects with their own unrelated self-image are the greatest criticism targets for a better and fairer change of life. The transfersal transformation begins from self to social transformation. This is a shift from personal analysis to social analysis. There is no promising change to live together in the future without being preceded by self-renewal. In the other shared relationships what is needed, primarily, not a change of reality, but a change of oneself.

72 Paulinus Yan Olla, Teologi Spiritual: Pengantar pada Teologi Spiritual, Tema-tema dan Strukturalisasi Pengajarannya, (Yogyakarta: Kanisius, 2010), 161-162.

73 Aloysius Pieris, God's Reign for God's Poor: A Return to the Jesus Formula: A Critical Evaluation of Contemporary Reformulations of the Mission Manifesto in Roman Catholic Theology and in Recent Jesuit Documents, (Gonawila-Kelaniya:Tulana Research Centre, 1999), 64-66. 


\section{BibLIOGRAPHY}

Abidin, Zainal. Filsafat Manusia: Memahami Manusia Melalui Filsafat. Bandung: Remaja Rosdakarya, 2006.

Batlajery, Agustinus M.L. "Keesaan Gereja Menurut Calvin dalam Institutio 1536". Studia 11, Nr. 1, (Maret 2011).

. "Calvin and Servetus: A Case of Violence and Calvin's Involvement". Sola Experientia 2, Nr. 1, (April 2014).

Bertens, K. Sejarah Filsafat Kontemporer: Prancis. II. Jakarta: Gramedia, 2014.

Calvin, John. Institutes of the Christian Religion. Ed. John T. McNeill. Louisville, Kentucky: Westminster John Knox Press, 2006.

Clark, S.H. Paul Ricoeur. London dan New York: Routledge, 1990.

Cottret, Bernard. Calvin: A Biography. T \& T Clark: Grand Rapids, Michigan, 1995.

Dankbaar, W.F. Calvin: Jalan Hidup dan Karyanya. Jakarta: BPK, 1967.

De Jonge, Christiaan. Apa itu Calvinisme? Jakarta: BPK Gunung Mulia, 2011.

Elwood, Christopher. Calvin for Armchair Theologians. Louisville, London: Westminster John Knox Press, 2002.

Fox, Matthew. Breakthrough: Meister Eckhart's Creation Spirituality in New Translation. New York: Image Books, 1980.

Hardiman, F. Budi. Kritik Ideologi: Menyingkap Pertautan Pengetahuan dan Kepentingan Bersama Jürgen Habermas. Yogyakarta: Kanisius, 2010.

Johnston, William. Mistik Kristiani: Sang Rusa Terluka. Trans. A. Soenarja. Yogyakarta: Kanisius, 1987.

. Teologi Mistik: Ilmu Cinta. Yogyakarta: Kanisius, 2001.

Jones, Serena. Calvin and the Rhetoric of Piety. Louisville, Kentucky: Westminster John Knox Press, 1995.

Leith, John H. The Reformed Imperative: What the Church Has to Say That No One Else Can Say. Philadelphia: The Westminster Press, 1988.

Kaplan, David M. Ricoeur's Critical Theory. New York: State University of New York Press, 2003.

Kerr, Jr., Hugh Thomson. A Compend of the Institutes of the Christian Religion by John Calvin. Philadelphia: Presbyterian Board of Christian Education, 1939 . 
Lonergan, Bernard J.F. Method in Theology. London: Darton, Longman \& Todd, 1975.

Martin, James P. “Toward a Post-Critical Paradigm”. New Testament Studies 33. Cambridge: Cambridge University Press, 1987.

Olla, Paulinus Yan. Teologi Spiritual: Pengantar pada Teologi Spiritual, Tema-tema dan Strukturalisasi Pengajarannya. Yogyakarta: Kanisius, 2010.

Pieris, Aloysius. God's Reign for God's Poor: A Return to the Jesus Formula: A Critical Evaluation of Contemporary Reformulations of the Mission Manifesto in Roman Catholic Theology and in Recent Jesuit Documents. Gonawila-Kelaniya: Tulana Research Centre, 1999.

Richard, Lucien Joseph. The Spirituality of John Calvin. Atlanta, Georgia: John Knox Press, 1974.

Ricoeur, Paul. Freud and Philosophy: An Essay on Interpretation. Trans. Denis Savage. New Haven: Yale University Press, 1970.

. The Conflict of Interpretations: Essays in Hermeneutics. Ed. Don Ihde. Evanston: Northwestern University Press, 1974.

. Interpretation Theory: Discourse and The Surplus of Meaning. Texas: The Texas Christian University Press, 1976.

. Essays on Biblical Interpretation. Ed. Lewis S. Mudge. Philadelphia: Fortress Press, 1980.

. Hermeneutics and the Human Sciences: Essays on Language, Action and Interpretation. Ed. John B. Thompson. Cambridge: Cambridge University Press, 1982.

. Lectures on Ideology and Utopia. Ed. George H. Taylor. New York: Columbia University Press, 1986.

. Time and Narrative. Vol. 3.Trans. Kathleen Blamey and David Pellauer. Chicago dan London: The University of Chicago Press, 1988.

. A Ricoeur Reader: Reflection and Imagination. Ed. Mario J. Valdes. Toronto dan Buffalo: University of Toronto Press, 1991.

. From Text to Action: Essays in Hermeneutics. II. Trans. Kathleen Blamey and John B. Thompson. Evanston, Illinois: Northwestern University Press, 1991.

. Oneself as Another. Trans. Kathleen Blamey. Chicago and London: The University of Chicago Press, 1992.

. Figuring the Sacred: Religion, Narrative and Imagination. Trans. David Pellauer. Minneapolis: Fortress Press, 1995. 
and Andre LaCocque. Thinking Biblically. Chicago and London: University of Chicago, 1998.

. The Rule of Metaphor. Trans. Robert Czerny, Kathleen McLaughlin and John Costello. London and New York: Routledge Classics, 2003.

Sheldrake, Philip. Spirituality and Theology: Christian Living and the Doctrine of God. Maryknoll, New York: Orbis Books, 1998.

Singgih, E.G. Mengantisipasi Masa Depan: Berteologi dalam Konteks di Awal Milenium III. Jakarta: BPK Gunung Mulia, 2005.

Song, Choan-Seng. Tell Us Our Name: Story Theology From an Asian Perspective. New York: Orbis Books, 1984.

Sumakul, H.W.B. Panggilan Iman dalam Teologi Luther dan Calvin: Suatu Kajian Etika Sosial Politik dalam Gereja Reformasi. Jakarta: BPK Gunung Mulia, 2016.

Thompson, John B. Critical Hermeneutics: A Study in the thought of Paul Ricoeur and Jürgen Habermas. Cambridge: Cambridge University Press, 1981.

Van den Brink, Gijsbert, dan Johan Smits. "The Reformed Stance: Distinctive Commitments and Concerns". Journal of Reformed Theology 9, (2015).

Van den End, Th. Enam Belas Dokumen Dasar Calvinisme. Jakarta: BPK Gunung Mulia, 2011. 